\title{
A Regular Monitoring of Iron Signifying the Quality of Water in Various Uses
}

\author{
Dr. Kumar Sourav ${ }^{1}$, Kumar Ashwani Kashyap ${ }^{2}$ \\ ${ }^{1}$ HOD, Department of Chemistry, St. Xavier's College, Dumka, S.K.M University, Dumka, Jharkhand \\ ${ }^{2}$ Assistant Professor, St. Xavier's College, Dumka, S.K.M University, Dumka, Jharkhand
}

\begin{abstract}
Iron is one of most abundant elements of the rocks and soil. All kinds of water including ground water have appreciable quantities of iron. Because of its more solubility at acidic $\mathrm{pH}$, therefore, large quantities of iron are leached out from the soil by acidic waters.
\end{abstract}

Keywords: Iron, having a functional role in living system, is an essential elements for plant and animal lives \& present in a number of biologically significant proteins. It participates in two main processes: oxygen-transport and electron-transfer. There are other molecules functioning as storer and tranporter of iron itself in the biological processes. The deficiency of iron in human body causes anaemia and weakness but large quantities result in haemochromatosis when tissue damage occurs due to excess of iron accumulation. Higher Fe ${ }^{+2}$ content found in drinking water of some areas of Dumka town caused red colouring of teeth of the inhabitants.

\section{Introduction}

A concentration of iron as low as $0.3 \mathrm{mg} \mathrm{L}^{-1}$ in water makes it unpalatable and stains laundry and plumbing fixtures. Higher concentrations are undersirable in water distribution systems as the flow of water is reduced due to the deposition of iron compounds. The growth of "iron bacteria" is also promoted, as these micro-roganisms derive their energy from the oxidation of $\mathrm{Fe}$ (II) and, on this account, a slimy coating deposits on the piping.

Iron occurs in conjunction with molybdenum in enzymes catalyzing nitrogen fixation. The chief heme-proteins are the hemoglobins, myoglobins, cytochromoes and some enzymes such as catalase and peroxidase, the functions and mechanisms of which are well documented in literature.

Iron is involved with copper in the natural selection of aerobic cells and in the evolution of metalloproteins and metalloenzymes. The evolution resulted in the development of copper-zinc enzymes (superoxide dismutase), hemeenzymes, iron-copper enzymes and oxygen-carrying proteins. The adaptation demanded eleborate storage and transport proteins, exclusively for iron and copper. Ceruloplasmin represents the latest example of the link between iron and copper in the vertebrates.

The pale blue-green colour of the aqueous iron (II) solution is on account of the species $\left[\mathrm{Fe}\left(\mathrm{H}_{2} \mathrm{O}\right)_{6}\right]^{+2}$. The potential of the $\mathrm{Fe}^{+3}$ to $\mathrm{Fe}^{+2}$ couple is such that molecular oxygen converts $\mathrm{Fe}$ (II) to $\mathrm{Fe}$ (III) in acid solution:

$$
\begin{gathered}
2 \mathrm{Fe}^{+2}+1 / 2 \mathrm{O}_{2}+2 \mathrm{H}^{+}=2 \mathrm{Fe}^{+3}+\mathrm{H}_{2} \mathrm{O}, \\
\mathrm{E}^{0}=0.46 \mathrm{~V}
\end{gathered}
$$

In basic solution, the oxidation is still more favourable:

$$
\begin{gathered}
1 / 2 \mathrm{Fe}_{2} \mathrm{O}_{3} \cdot 3 \mathrm{H}_{2} \mathrm{O}+\mathrm{e}=\mathrm{Fe}(\mathrm{OH})_{2}(\mathrm{~S})+\mathrm{OH}^{-} \\
\mathrm{E}^{0}=\_0.56 \mathrm{~V}
\end{gathered}
$$

Thus, ferrous hydroxide, when precipitated in presence of air, rapidly becomes dark and is finally converted into
$\mathrm{Fe}_{2} \mathrm{O}_{3} \cdot \mathrm{nH}_{2} \mathrm{O}$. Because of $\mathrm{Fe}$ (III) remaining in the form of hydroxo-complexes, except in extremely acid solution, and for kinetic reasons, oxidation becomes less rapid with increasing acidity.

The oxidation of $\mathrm{Fe}$ (II) to $\mathrm{Fe}$ (III) by molecular oxygen in neutral solutions may involve a reaction between $\mathrm{Fe}(\mathrm{OH})^{+}$ and $\mathrm{O}_{2}$. The related problem of oxidation of $\mathrm{Fe}^{+2}$ by $\mathrm{H}_{2} \mathrm{O}_{2}$ (Fenton's reagent) is complicated and involves radicals generatred by the reaction:

$$
\mathrm{Fe}^{\mathrm{II}}+\mathrm{H}_{2} \mathrm{O}_{2} \longrightarrow \mathrm{Fe}^{\mathrm{III}}(\mathrm{OH})+\mathrm{OH}^{-}
$$

In the absence of strong complexing agents, iron selectively combines with $\mathrm{OH}_{-}$available at $\mathrm{pH}>7$ and alternates between the forms $\mathrm{Fe}(\mathrm{OH})^{+}{ }_{2}, \mathrm{Fe}(\mathrm{OH})^{-}{ }_{4}$.

Complex formation has a direct bearing on the toxicity of the metal, it can also affect the redox potential of the system and eventually, many other properties including biochemical. Theis and Singer (1974) have shown that various humic acids as tannic and gallic acids, can completely retard the oxidation of $\mathrm{Fe}(\mathrm{II})$ for several days. They describe the behaviour of Iron in the presence of organic matter and oxygen according to the following scheme.

In water, iron occurs both in the divalent and trivalent states. In surface water, it is generally present as $\mathrm{Fe}(\mathrm{III})$. The concentration of iron in the well aerated water is seldom high but under reducing conditions which may exist in some ground water, lakes or reservoirs and in the absence of sulphate and carbonate, high concentrations of soluble Fe(II) may be found.

\section{Conclusion}

The presence of iron in natural water can be attributed to the leaching of rocks and minerals, acid mines drainage, ferrous metallurgy, landfill leachates, sewage and engineering 
industries. Ferrous metallurgy is the principal anthropogenic source of iron starts right from the handling and sintering of the ore, hematite. Blast furnace in itself was a great source of iron emission. However the high $\mathrm{CO}$ - content of the waste gases now makes them a valuable fuel for other kinds of operations in the steel works. The tremendous evolution of fine orange brown fumes from the oxidative processes in steel converters pose a great threat to environment.

\section{References}

[1] West, Larry : "World Water Day ; A Billion People Worldwide Lack Safe Drinking Water", (2006).

[2] United States Environmental Protection Agency (EPA). Washington, DC. "The National Water Quality Inventory: Report to Congress for the 2002 Reporting Cycle - A Profile."

[3] EPA. "Protecting Water Quality from Agricultural Runoff." Fact Sheet No. EPA-841-F-05-001. March 2005.

[4] C. Michael Hogan : "Water pollution." Encyclopedia of Earth. Topic ed. Mard McGinley;ed. in chief C. Cleveland. National Council on Science and the Environment, Washington, DC, (2010).

[5] EPA. "IIlness Related to Sewage in Water." Accessed February 20, 2009 